Оригинални научни рад

УДК 821.163.41.09:398.21

Примљен: 22. септембра 2020.

Прихваћен: 1. октобра 2020.

https://doi.org/10.46630/phm.13.2021.38

Александра 3. Миљановић ${ }^{1}$

Универзитет у Београду

Филолошки факултет

Катедра за српску књижевност са јужнословенским књижевностима

\title{
ОБРЕДИ ПРЕЛАЗА У ЖЕНСКИМ БАЈКАМА СРПСКОГ УСМЕНОГ КОРПУСА
}

У раду се пружа анализа елемената обреда прелаза у женским бајкама српског усменог корпуса (В. С. Караџић, В. Чајкановић, Д. Ђорђевић, В. Бован, С. Марковић, Д. Златковић), који се понајвише уочавају у мотивима иницијације, трудноће и свадбе. Највише простора посвећено је иницијацији, која у женској бајци подразумева одређене теме, мотиве и просторе. У свом корену, женска иницијација везана је за простор куће (Пепельга). Слободним мешањем са другим типовима бајки, па и бледењем самих обреда у традицији, јунакиња је постепено напуштала кућу (круг бајки о маћехи и пасторки), да би напослетку и сама могла, као мушки јунак, да „пође у свет” (круг бајки о потрази жене за изгубљеним мужем).

Кључне речи: женска народна бајка, обреди прелаза, иницијација, Пепељуга, бајке о прогоњеној јунакињи, бајке о маћехи и пасоторки, бајке о потрази жене за изгубљеним мужем

\section{1. Женске народне бајке}

Термин женска бајка неретко може изазвати недоумице у тумачењу, нарочито ако се у обзир узме Вукова дефиниција бајки, тј. народних приповедака уопште, према којој Вук све бајке одређује као женске, разликујући их од мушких приповедака по присуству фантастичних елемената.

Међутим, ако оставимо по страни присуство фантастике, бајке се непосредно могу поделити на мушке и женске и то најчешће према типу главног јунака. Тако би женске бајке биле оне у којима је централни лик јунакиња. Појава женског јунака као главног лика у бајци подразумева и нарочити тип бајке, тј. специфичне сижее, теме, мотиве, просторе којима се јунакиња креће и послове које обавља, те се може говорити о извесном женском принципу у овом типу бајки, који се огледа у често

1 aleksandra.miljanovic1@gmail.com 
неизоставном мотиву мајке, амбијенту куће и атрибутима женских послова попут вуне, вретена и различитих житарица. Такође, женска бајка се од јуначке разликује, на пример, и по животињама које се јављају у функцији помагача. У женским бајкама су то углавном петлови, мачке и пси. Изузетак у прегледаном корпусу је бајка Omau, и юегове кћерu (С̌, 48) (AaTh 514), о којој ће посебно бити речи.

Бајке са главним женским ликовима најчешће припадају кругу бајки о породичним односима и то типовима бајки о прогоњеној девојци, о маћехи и пасторки и девојци без руку (LATKOVIĆ 1987: 99-100). Као женске бајке такође се могу посматрати приповетке о жени у потрази за мужем, које припадају кругу бајки о зетовима животиюама (LATKOVIĆ 1987: 92).

Женске бајке, тј. бајке уопште, свакако пружају обиље материјала за тумачење са различитих аспеката. Приметно је да су женске бајке нарочито „омиљене” када је у питању психоаналитичко и јунгијанско тумачење, посебно када се у обзир узму обреди прелаза који стоје у уској вези са променом јунака. ${ }^{2}$ Аспекти обреда прелаза у бајкама, који се у овом раду тумаче првенствено са становишта фолклористике и етнологије, са јунгијанског становишта тумаче се понајвише у светлу женске индивидуације, о чему говоре бројне студије Мари Луиз фон Франц. Такво тумачење бајки слило се и у дела популарне књижевности, у којима ауторке у бајкама траже упориште за интерпретацију снова својих клијенткиња са психотерапија. ${ }^{3}$ Такође, веома је популарно тумачење женских бајки (нарочито обреда иницијације) у светлу феминистичке критике.

\section{2. Обреди прелаза у бајкама}

Овој групи обреда нарочиту пажњу посветио је Арнолд ван Генеп у свом капиталном делу Обреди прелаза: систематско изучавағе ритуала, где примећује да се „живот појединца састоји из сукцесивних етапа чији се крајеви и почеци спајају у један низ: рођење, друштвено сазревање, брак, очинство, успон на друштвеној лествици, специјализација у послу, смрт" (VAN GENEP 2005: 7). Стога би се обреди прелаза могли разумети као оне церемоније које одговарају свакој од наведених етапа и „имају заједнички циљ да појединца спроведу из једног одређеног стања у друго, исто тако одређено, стање” (VAN GENEP 2005: 7).

2 „Но, као да је у бајци важна сама промена јунака. Та усмереност од трудноће ка рођењу и од рођења ка сазревању дала је повода различитим психолошким тумачењима бајке. Јунак бајке по њима је дете које сазрева, постаје одрасло, одбацује своје дечје стање и прелази у стање одраслог. Тако бајке виде не само аналитичар Бетелхајм него и следбеници Јунгове школе." (RADULOVIĆ 2009: 30).

3 На пример Жене које трче с вуковима Кларисе Пинколе Естес; код нас - Чудесно у нама Сање Димоски. 
Бајка је као усмена уметничка творевина богата архаичним значењским слојевима традиције и културе који се уочавају у самом сижеу, употреби мотива, метафора и идеја. Како бајка неретко казује о иницијацији и ритуалним проверама и ретко изоставља женидбу јунака, тј. удају јунакиње, бројни проучаваоци су у бајци уочили уметнички транспоноване обреде (прелаза), па чак и само порекло бајке изводили из истих.

Владимир Проп у Историјским коренима бајке испитује однос бајке и обреда и изводи неколике могућности тог односа (PROP 2013:1922). Својом теоријом о постанку народне бајке Проп доноси закључак да бајка води порекло управо из иницијације као обреда прелаза, те да мотив шуме/куће у шуми, који је веома чест у бајци, увек и изнова „изазива питање о вези одређеног сижеа са циклусом феномена иницијације” (2013: 63).

Мелетински у Поетици мита такође разматра однос бајке и ритуала и значење обреда прелаза. Међутим, иако придаје велики значај иницијацији, Мелетински у испитивању структуре и порекла бајке за разлику од Пропа примат над иницијацијом даје свадби, те закључује да „постоји део истине и у тврдњи да је иницијација ритуални еквивалент мита (и архаичних форми народне приче), а свадба - развијене бајке” (MELETINSKI 1983: 271). Штавише, Мелетински сматра да се бајка „може упоредити и са свадбеним обредом у целини, стога што је женидба царевом кћери или брак са царевићем њен крајњи циљ” (1983: 271).

Када је у питању однос између бајке и обреда, и тумачења српске етнологије и фолклористике проналазе различите везе између обреда прелаза и структуре или мотива бајке.

Драгана Антонијевић у Значену српске бајке, следећи понајвише теоријске идеје Пропа и Мелетинског ${ }^{4}$, уочава везе између наративне структуре српске (јуначке) бајке и структуре обреда прелаза, нарочито иницијације. Такође, у раду Антрополошко поимаюе бајке као оптимистичког жанра примењује структуру обреда на општу структуру бајке, при чему издваја фазе (маргиналност, сепарација, лиминалност, агрегација) кроз које јунак пролази (ANTONIJEVIĆ 2013: 11).

Значајан допринос посматрању женске народне бајке у контексту обреда прелаза представља рад Снежане Самарџије о Пепељуги (Облици усмене прозе, Круг приповедака о прогоюеној девојии) и иницијацији у женским бајкама уопште, о чему ће посебно бити речи.

4 Антонијевић у овој студији примењује и теорију Жилијена Гремаса (Структурална семантика) која доноси редукцију Пропових функција и проналази уговор као основу бајке, где заповест/прихватаюе означава уговорну одредбу, а забрана/кршеюе означава прекид уговора (GREMAS 1987: 298-300). 


\section{3. Бајке о прогоњеној јунакињи}

Женске народне бајке већином се могу сврстати у круг приповедака о породичним односима, тачније у тип бајки о прогоњеној девојци (Пепељуга, маћеха и пасторка, приповетке о девојци без руку).

Оно што је заједничко свим овим бајкама јесте позиција главне јунакиње која је несрећна и прогоњена од стране маћехе/свекрве/оца. Девојка је стављена пред тешке задатке које треба да испуни, а који су

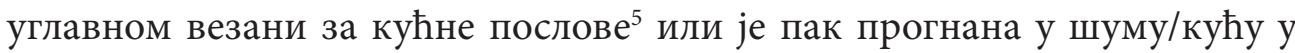
шуми/воденицу. Оба мотива имају карактер обреда прелаза, јер се девојка налази у улози искушеника и пролази кроз обред иницијације, после којег стиче нови статус (обред прелаза - свадба) или стиче углед у породици (у односу на маргинално стање у којем је прогоњена).

У том погледу, чини се да се два обреда прелаза највише уочавају у овом типу бајки - иницијација и свадба. Рођење јунакиње се не помиње јер бајка отпочиње временом у којем је јунакиња девојка, са претпоставком да су у питању године у којим је спремна за удају. ${ }^{6} \mathrm{C}$ друге стране, смрт главног јунака је веома редак мотив у бајкама и сходно томе се не обликује као обред прелаза ни у овом типу бајки.

\section{1. Пепељуга}

Народна приповетка о Пепељуги (AаTh 510 A) представља једну од највише распрострањених бајки на свету и јавља се у бројним варијантама код многих народа. Управо због тога, ова бајка је једна од омиљених и када је у питању тумачење, нарочито јер је богата слојевима који пружају могућност за тумачење са различитих аспеката. ${ }^{7}$

У прегледаном српском усменом корпусу најразвијенији наративни ток имају варијанте из збирке Драгутина Ђорђевића (Đ, 63), Снежане Марковић $(\mathrm{M}, 10)$ и варијанта из Вукове збирке $(\mathrm{V}, 32)$, која има најдоследније фабуларно језгро (SAMARDŽIJA 2011: 114). Варијанте Đ, 63 и $\mathrm{V}, 32^{8}$ одликују се специфичним почетком, у којем је мотивисана даља Пепељугина позиција прогоњене јунакиње. Наиме, за разлику од интернационалних варијанти које почињу смрћу мајке, ове бајке почињу кр5 „По Пропу иницијацијски тест у женској бајци има карактер домаћих послова.” (RADULOVIĆ 2009: 81).

6 „Носиоци радње су увек младићи и девојке, стасали за брак, или тек венчани млади пар, због чега су проучаваоци и могли да успоставе дубинску везу са структуром жанра и исконских обреда прелаза." (SAMARDŽIJA 2011: 143).

7 Једно од популарних тумачења свакако је Бетелхајмово, који у бајци о Пепељуги види „унутарње доживљаје малог детета у мукама супарништва с браћом и сестрама, када се осећа безнадежно надјачано од њих" (BETELHAJM 1979: 260).

8 У варијанти M, 10 јунакињина мајка се претвара у краву након смрти. 
шењем забране 9 , т.. табу прописа који изазива сама јунакиња испустивши вретено у јаму $\left(k^{1} q^{1}\right)^{10}$. Кршење забране ,узрокује метаморфозу мајке у краву, довођење маћехе и даљи низ издвајања" (SAMARDŽIJA 2011: 116) и изазива „нарушавање равнотеже, неопходно за ритам авантура у бајци” (SAMARDŽIJA 2011: 116).

Самарџија примећује да Вукова варијанта садржи бројне аспекте који путем сижејно-мотивског склопа комуницирају са обредима прелаза, иницијацијом, култом предака и мртвих и култом плодности. Већ у иницијалној позицији Пепељуга, испуштајући вретено у јаму, крши забрањену везу са мртвима (SAMARDŽIJA 2011: 116), тј. „сви предмети, животиње и биље с којима Вукова Мара долази у додир, значењски се преклапају, а имају посебну улогу у обредима посвећеним мртвима" (SAMARDŽIJA 2011: 117).

У бајци о Пепељуги (V, 32) постоје бројни индикатори у тексту који упућују на то да Мара пролази кроз обред иницијације. Најпре, јунакиња је стављена пред тешке задатке, који се, како је већ речено, у женским бајкама јављају у виду кућних послова. ${ }^{11}$ у делокругу противника $(P)$ је лик маћехе чија је функција „прогањање” тј. задавање тешких задатака. Први задатак везан је за предење и он се градацијски усложњава јер маћеха увек даје још више кудеље. Други задатак везан је за сакупљање проса, који се градацијски отежава као и претходни. У делокругу помоћника у тешким пословима $(A)$ је лик мајке-краве и два голуба. Комуникација коју Пепељуга остварује са умрлом мајком/кравом симбол је комуникације са култом предака и мртвих, јер помоћ у пословима стиче када се обрати мајчином гробу, тј. костима. ${ }^{12}$

Изолованост ${ }^{13}$ такође представља један од аспеката обреда ини-

9 У бајкама је јунаку или јунакињи речено да не ураде нешто, а протагониста, наравно, крши забрану. Фолклористички оквир не само да дозвољава, већ и захтева табу акцију (DANDES 2007: 59-60).

10 У заградама наводимо Пропове функције.

11 „Мотив покоравања као основни став у потпомагању успешног обреда иницијације може се јасно видети код девојака или жена. Њихов обред преласка на почетку истиче њихову суштинску пасивност, а то је појачано физиолошким ограничењем њихове самосталности." (HENDERSON 2017: 118)

12 „Од свих веровања о (органској) души најзанимљивије и, по својим последицама, најплодније је веровање да је душа везана за кости [...]. Док постоје кости, дотле живи и душа, и према томе постоји могућност за евентуално ускрснуће." (С̌AJKANOVIĆ 2014: 456).

„У причи о „Пепељуги“ наређује мајка претворена у краву својој кћери да, када њу краву - закољу, покупи кости и склони их - очевидно у циљу да би крава доцније могла оживети.“ (С̌AJKANOVIĆ 2014: 456 - 457).

13 Познато је да су код многих народа девојке у добу пубертета биле подвргнуте ритуалном одвајању, те затваране у кућу или колибу (FREJZER 1977: 304-316). 
цијације. Пепељугина сфера кретања је ограничена на простор куће, а једини излазак је одлазак на литургију, који се може разумети као „награда" култа предака, јер је прописним сахрањивањем костију јунакиња прошла посебну проверу (SAMARDŽIJA 2011: 119). Такође, на литургији Пепељугу нико не препознаје ${ }^{14}$ (обучена је у раскошне хаљине), те она иако излази из куће, остаје прикривена.

У светлу обреда иницијације и прелазних стања кључан је и тренутак Пепељугиног губљења папуче, јер се враћа кући храмљући, те „хрома, јунакиња завршава један циклус, једну етапу пута и припремљена је да почне нову" (SAMARDŽIJA 2011: 119).

Последња фаза Пепељугиног прикривања је скривеност под коритом. Како преврнуто корито „има облик погребног ковчега и асоцира на раку" (SAMARDŽIJA 2011: 120), овај мотив упућује на завршну фазу обреда иницијације ${ }^{15}$, тј. „симболичну привремену смрт и контакт с духовима, који отвара пут за оживљавање или, тачније, за поновно рођење у новом својству"(MELETINSKI 1983: 230). Пепељугино буђеґе из таме, откриване и поновно рођене симболизује оглашавање петла ${ }^{16}$ чиме је завршена „провера предака и Пепељуга је спремна за нови статус у заједници"(SAMARDŽIJA 2011: 120). Пепељугин нови друштвени статус обележен је удајом за принца, те би обред иницијације заправо означавао „проверу” за потоњи обред прелаза - свадбу.

Иако је уочено да постоји велики број аспеката који одговарају обредима прелаза, те посебно иницијацији, општа структура Пепељуге доноси извесне разлике у односу на структуру обреда прелаза која се примењује у поређењу са структуром (јуначке) бајке.

Наиме, кључне разлике уочавају се у фазама сепарације и лиминалности. У фази маргиналости, Пепељуга крши забрану и налази се у почетном стању у позицији прогоњене јунакиње, а крајња фаза агрегащије доноси промену статуса у односу на почетну фазу и обележена је свадбом. Сепарација у јуначкој бајци подразумева одлазак од куће и постављање тешких задатака, а лиминалост боравак у оностраном простору, те искушења и решавања задатака. Међутим, како је већ речено, 14 Непрепознавање неофита је карактеристично за обред иницијације и сачувано је у бајкама (RADULOVIĆ 2009: 135).

15 „Иницијацијска смрт није физиолошка, то је смрт у односу на свет [...]. Новообраћеник, изгледа, доживљава регресиван процес, његово поновно рађање се упоређује с повратком у фетално стање, у мајчину утробу. Он заправо продире у таму, али таму која се њега тиче [...]" (RS 2004: 293).

16 „Петао је соларни и хтонски симбол (птица која хода са великом оплодном моћи). Он дели чисто и нечисто време ноћи и тера нечисту силу." (RADENKOVIĆ 1996: 68) „Према општераспрострањеном схватању, петлово певање представљало је неку врсту временске границе: њиме се време делило на оно које припада демонима и оно које припада људима."(BANDIĆ 2004: 41). 
Пепељугина сфера кретања је веома сужена и обухвата простор куће, тј. поље кретања које је блиско кући (гроб и црква) ${ }^{17}$, што упућује на специфично приказивање и постављање „активности” у женској бајци, које утиче и на саму природу обреда иницијације.

„Кућа је заштићен „свој” простор, „мајчински” симбол” (RADULOVIĆ 2009: 36). То на плану сижејности означава да у кући нема активности и да радња отпочиње тек напуштањем куће (RADULOVIĆ 2009: 36). Међутим, то је карактеристично за мушке бајке. У женским бајкама, нарочито у типу Пепељуге, почетак радње обележен је „уласком новог, туђег члана у домаћи простор" (RADULOVIĆ 2009: 36). У том погледу, долазак маћехе еквивалентан је одласку „у свет” у мушким бајкама, па би управо у бајци о Пепељуги представљао фазу сепарације.

Из такве природе женске бајке произилази и чињеница да се сви Пепељугини тешки задаци одвијају у простору куће. С тим у вези, кључно је огњиште ${ }^{18}$ које има битну улогу у обредима прелаза. ${ }^{19}$ Стога би се боравак крај огњишта у Пепељуги могао схватити као пандан боравка у оностраном простору у јуначким бајкама и означавао би фазу лиминалности.

Веома блиске типу Пепељуге јесу неколике варијанте о мајци крави из збирке Драгутина Ђорђевића (Đ, 59, 60, 62) и збирке Драгољуба Златковића $(Z, 89,90,92,94,95)$. Иако у овим бајкама изостаје мотив пепела, ове бајке показују бројне сличности са варијантом Пепељуге и уочавају се у мотивима везаним за култ мртвих (мајчин гроб) и култ плодности. ${ }^{20}$ Такође су присутни мотиви тешких задатака које задаје маћеха. У том погледу, варијанте 90. и 92. из Златковићеве збирке најсличније су типу Пепељуге. Међутим, наративна структура појединих бајки показује и извесне разлике у односу на Пепељугу. Бајке су доста сажетије, а њихов наративни склоп се одликује гранањем појединих мотива у различитом

17 Тачке Пепељугиног мировања/кретања - јама, огњиште, гроб, црква - укључене су „у све обреде прелаза и ритуалне посвећене мртвима” и „директно се повезују са женским архетипом" (SAMARDŽIJA 2011: 117).

18 „Огњиште, средиште куће, симбол је мајке. Живети тако близу огњишта да човек обитава сред пепела може симболисати покушај држања за мајку, или враћања мајци и оном што представља." (BETELHAJM 1979: 271).

19 Управо су се за огњиште везивале „многе ритуалне радње чија је сврха била да обезбеде помоћ, учешће или сагласност божанстава доњег и горњег света, нарочито приликом ритуала прелаза који су и иначе типично породичног карактера (свадба, рођење, увођење у зрелост, смрт) и у оквирима такође типично породичних култова, какви су пре свега култ предака и култ мртвих" (DETELIĆ 1992: 135).

„Душе предака налазе се на огғишту, односно у ватри на огњишту, па онда у оџаку који се налази изнад огњишта" (С̌AJKANOVIĆ 2014: 462).

20 Већ сам наслов упућује на овај култ, јер крава означава култ плодности (RS 2004: 422). 
правцу. У бајци Z, 89 на месту где су закопане кости мајке-краве изникла је златна јабука, те јунакиња једина успева да убере њен плод, а потом се удаје за принца. Бајка Đ, 59 поред тешких задатака који су провера за свадбени обред прелаза, такође познаје и мотив претварања јунакиње у гугутку, а потом и кажњавања прогонитеља, тј. нељубазне девојке. У бајци Каракониула $(Đ, 60)$ уочава се контаминација са етиолошким предањем, те се одликује радикално другачијим крајем, јер јунакиња не успева да изврши задатак, те завршава својеврсном метаморфозом: „Пасторкиња је цео дан прала и плакала, а вуна неће да постане бела и девојка проговори: - Претвори ме, Боже, у мечку да одем у шуму. И тако би” (Đ, 60). У веома сажетој бајци Мајка се претворила у краву (Đ, 62) тешки задаци губе карактер обреда иницијације, а свадба као обред прелаза, тј. награда, потпуно изостаје, те се напросто нижу задаци и помоћ која следи од мајке-краве.

\section{2. Бајке о маћехи и пасторки}

Круг бајки о маћехи и пасторки, које припадају типу љубазних и нељубазних девојака, у односу на бајке типа Пепељуге могао би се симболички означити као напуштаюе куће. Док Пепељуга извршава задатке и пролази кроз провере у амбијенту куће, јунакиње ових бајки удаљавају се до простора шуме/воденице који играју кључну улогу у остваривању обреда иницијације. Чини се да је посреди комбинација два обрасца бајки (круг бајки о прогоњеној пасторки и круг бајки о јунаку који пролази кроз провере) која је остварена због њихове семантичке блискости (SAMARDŽIJA 2011: 122). Ипак, за разлику од јуначких бајки, „девојка јунакиња не одлази у друго, удаљено царство, као мушки јунак. Она иде у простор који је „тућ” (и одговарајући за иницијацијске тестове), али не и толико далек (шума, воденица)" (RADULOVIĆ 2009: 54). Такође, ако је за женске иницијације карактеристично да се одигравају у простору куће, тј. да је кључна изолованост девојака, ове бајке говоре и о извесном губљењу актуелности, смисла и улоге иницијације услед наноса нових епизода и заплета (SAMARDŽIJA 2011: 123).

Тумачећи круг бајки о маћехи и пасторки у светлу обреда прелаза, треба напоменути да и сама маћеха, иако је њен лик примаран у функцији прогонитеља, пролази кроз ове обреде, јер њеном доласку у јунакињину кућу свакако претходи свадба, тј. удаја за јунакињиног оца. Такође, долазак маћехе представља и кршење локалне ендогамије „ако се имају на уму правила о склапању брака” (ANTONIJEVIĆ 1991: 80). У нашој традицији ограничења ендогамних односа имају карактер табуа, те ова забрана „има у народу религијски садржај. Санкције које сустижу прекршиоце могу се схватити само као резултат одговарајуће интервен- 
ције натприродног" (BANDIĆ 1980: 343).

Већина бајки о маћехи и пасторки одликује се сличним фабуларним током који у себе укључује мотиве тешких задатака које задаје маћеха, напуштање куће, те одлазак у шуму, колибу или воденицу. Сви ови мотиви у тумачење призивају обред иницијације, али не увек обред иницијације као сегмент обреда прелаза.

Бајка Маћеха и пасторка (V, 34) по одређеним мотивима представља изузетак када је у питању посматрање варијанти бајки овог типа, jep се у њој иницијација обликује као део обреда прелаза, те као у типу Пепељуге представља проверу јунакиње пред свадбу. У овој бајци девојку у шуму, за коју је већ речено да готово увек призива обред иницијације, одводи отац. Фигура оца у бајци је такође кључна за тумачење овог обреда, ,jер је место на коме се вршио обред било женама забрањено” (PROP 2013: 95). Протеривање сопствене ћерке мотивисано је „непријатељством" које у породицу доноси улазак новог лица у породицу, тј. маћехе ${ }^{21}$ која и јесте „главни иницијатор протеривања деце у шуму” (PROP 2013: 97). Јунакиња у шуми наилази на колибу, а „то је стални део инвентара обреда, као и шума" (PROP 2013: 68) и у њој животиње које храни. Мотив помоћи животињама карактеристичан је и за друге бајке овог круга, али се ова бајка може сматрати јединственим примером због мотива доласка младића прерушеног у медвеђу кожу, за кога ће се јунакиња потом и удати. У том погледу, обред иницијације у овој бајци, уочен у мотивима шуме, колибе и „провере” од стране животиња, укључен је у циклус прелазних обреда и претходи свадби као обреду прела-за.

Варијанте бајки о маћехи и пасторки (V, 36), (亡̌, 51), (Đ, 51, 52, 53 , $54,55,57),(\mathrm{M}, 26,27),(\mathrm{Z}, 74,77),(\mathrm{B}, 41)$ одликују се веома сличним сижеом. Маћеха поставља тежак задатак - јунакиња мора да претвори црну вуну у белу (Đ, $52,53,54 ; 3,74)$ или/и да ноћу борави и ради у воденици, што представља гранични хронотоп (С̆, 51; Đ, 53, 54, 55; M, 26, 27; Z, 77). „И док маћеха поставља немогућ захтев, фантастични помоћник најчешће тражи да га девојка побиште или обави уобичајене кућне послове. Пасторку и маћехину кћер куша женски демон, било да антропоморфно биће борави крај воде, означава се као ала или, најчешће, баба у чијој су власти хтонске животиње, односно целокупна фауна" (SAMARDŽIJA 2011: 123). Крај доноси опозицију између судбине љубазне и нељубазне девојке ${ }^{22}$, јер љубазна јунакиња стиче/враћа углед и стиче благо, а нељу-

21 „Питамо се: зашто маћеха сама не може одвести пасторку, или пак пасторка? Зашто, уз своју окрутност и бес, она сама својом руком не одводи децу у шуму? Она би то могла урадити логички, али историјски не може, будући да историјски децу одводи у шуму увек само отац, или брат, или стриц, али то никад није радила жена. То је могао урадити само мушкарац, и мушкарац у тој улози није сасвим потиснут у бајци.” (PROP 2013: 98). 22 Тип бајке о љубазној и нељубазној девојци контрастом приказује добро и лоше 
базна девојка пролази несрећно или чак умире: „Финална формула заснована доследно на бинарном пару награда: казна, омиљеном у бајкама, реализује се кроз овај приповедни тип као однос између (пасторкиног) почетка новог живота и смрти (полусестара)" (SAMARDŽIJA 2011: 124).

Нешто сложеније варијанте овог типа бајки су Маћија и пасторкиња $(Ð, 56)$ и Пасторка $(\mathrm{B}, 41)$. У бајци Маћија и пасторкиюа $(Ð, 56)$ такође је истакнута опозиција између награде/казне и судбине љубазне и нељубазне девојке, али за разлику од претходних варијанти, јунакиња кроз искушења пролази у бунару. ${ }^{23}$ Интересантно је да је у самој бајци бунар означен као онај свет: „Једног дана предложи пасторки да ће је бацити у бунар, јер испод бунара има други свет (подземни свет), да тамо тражи срећу." (Đ, 56). Боравак јунакиње у бунару би стога одговарао фази лиминалности. У бајци Пасторка (B, 41) јунакиња извршавајући задатак који задаје маћеха, доспева у провалију, а потом у кућу старице, која има девет соба. У том погледу, у овој бајци конституише се и мотив забрањене одаје, који је кључан на сижејном плану, јер покреће мотив награде/ казне која следи љубазној, тј. нељубазној девојци.

Мотиви тешких задатака, изолованости у воденици/колиби/бунару и провере свакако упућују на искушења и извесне елементе обреда иницијације кроз који пролази главна јунакиња. Такође, елементи иницијације уочавају се и у бирању најнеугледнијег од понуђеног (RADULOVIĆ 2009: 80) и самилости према животињама (RADULOVIĆ 2009: 84). Међутим, оваква иницијација се не може приписати обредима прелаза ${ }^{24}$, јер јунакиња не стиче нов статус у друштву нити „пролази” у нов животни период. Она само пролази кроз искушења да би стекла „награду” у виду блага или побољшане позиције у друштву, тј. породици. Дакле, нема „правог” поновног рођења нити свадбе, тј. фаза агрегације обележена је реинтеграцијом у премаргинално стање.

У бајци Зла маћеха (V, 33) (AaTh 706) фаза агрегације је такође обележена сличном реинтеграцијом, али се мотиви обреда иницијације проналазе у нешто потпунијем, па и другачијем облику. На наговор маћехе јунакињу слуге одводе у шуму и имају задатак да јој одсеку руке ${ }^{25}$ и

понашање две девојке, те показује како љубазна девојка која брине о животињама, чисти и кува бива богато награђена, док њена лења и себична полусестра бива кажњена (HOLBEK 1987: 421).

23 „Осмишљен је као погранични простор, веза са оностраним светом.” (SM 2001: 58).

24 Ван Генеп напомиње да нису сви обреди иницијације, рођења, венчања итд. искључиво обреди прелаза, јер сви ритуали имају и своје појединачне циљеве (2005: 16).

25 О овом мотиву подробно пише Павле Поповић у студији Приповетка о девојци без руку. Испитујући порекло овог мотива у српским народним приповеткама, Поповић сматра да ова бајка припада другом типу приповедака о девојци без руку (1905: 6), те да води порекло из Миракула (1905: 94). 
изваде срце. Девојка остављена осакаћена у шуми пролази кроз обред иницијације у потпуној изолованости од света, на ивици смрти. Својеврсно поновно рођеґе јунакиња доживљава пошто је отац поспе прахом ${ }^{26}$ насталим од длака сеновитих животиња: „Пошто је отац виђе заплака се па паде над њом, и видећи је без рука посу је онијем прахом од репова коњскијех, те она оживље у они час и друге јој руке изникоше - не од меса, него од сухога злата. " $(\mathrm{V}, 33)$.

\section{3. Отац као прогонитељ}

Круг приповедака о прогоњеној јунакињи обухвата и тип бајки у којима се као противник појављује лик оца (AaTh 510 B). Прогањање јунакиње од стране оца праћено је инцестуозним намерама. Мотив очевог инцестуозног прогањања представља покушај кршења егзогамије и алтернативан је мотиву маћехе и пасторке (MELETINSKI 1983: 272).

У варијантама о оцу прогонитељу (V, 28, Цар хтео кћер да узме; $Đ, 64,65,66)$ очево кршење егзогамије последица је уговора са женомцарицом који је остварен пред њену смрт и прихватања царичиног наређења (ANTONIJEVIĆ 1991: 86). У том погледу, јунакиња која се одупире очевој жељи представља прекршиоца уговора и стога сноси одређене последице - изгнанство (ANTONIJEVIĆ 1991: 95) или смрт. Отац бира кћер за будућу супругу јер само њеном прсту одговара одабрани прстен (V, 28 ), или пак због чудесног обележја - звезда на челу (V, Цар хтио кћер да узме; Đ, 65) или круне на челу (Đ, 64). У светлу обреда прелаза, овај тип бајки обележен је јунакињиним напором да се обред прелаза (свадба) не оствари.

Бајка Царева кћи овца (V, 28) (AaTh 510B, AaTh 706) поред мотива о инцестуозном оцу, садржи и мотив одсецања руку. За разлику од приповетке Зла маћеха, у којој јунакињи по наредби секу руке, у овој бајци јунакиња сама себи одсеца руке ${ }^{27}$, што се обликује као мотив помоћу којег девојка спречава свадбу ${ }^{28}$, ККад шћер ово дочује, узме очину сабљу те сама себе лијеву руку осијече, а десну у огњу изгори. Ујутру слуге приправљају свадбу, а један од њих докаже цару како му је видио шћер без рука" (V, 28). Како јој руке поново израстоше, јунакиња намерно узима забрањени штап и претвара се у овцу, да би на крају умрла истог дана

26 „Сваки обред иницијацијског умирања се састоји од посебних поступака. Кандидат може бити [...] посут прахом." (РС 2004: 293).

27 Поповић ову бајку сврстава у први тип приповетке о девојци без руку (1905: 3) и сматра да се сачувао само њен почетак (1905: 62-63).

28 Антонијевић примећује да Дандес „даје занимљиву и значајну опаску у вези с овим мотивом, сматрајући да је „одсецање руке“ супротно од појма „дати неком своју руку“ што је уобичајени израз за просидбу и склапање брака” (1991: 99). 
када и цар. Овакав радикалан обрт чини се прилично немотивисаним у односу на први наративни део. Нарочито је смрт главне јунакиње веома редак мотив у бајкама. Метаморфоза у овцу ${ }^{29}$ нема посебну метафоричку димензију, те „овакви процеси, мешање и преплитање два иницијацијска модела, показују удаљавање од обреда, његово заборављање и потпуни прелаз из ритуалне праксе у стилизовану форму" (SAMARDŽIJA 2011: 124). Ипак, јунакиња све чини како би избегла свадбу са сопственим оцем, па уместо венчања као обред прелаза бира смрт.

Друге варијанте о оцу и прогоњеној јунакињи (V, Цар хтио кћер да узме; $Đ, 64,65,66)$ имају другачији наративни ток. У њима нема мотива о претварању у овцу и нема смрти јунакиње, већ остаје само почетна намера кршења егзогамије. Јунакиње ових бајки одлажу и избегавају свадбу са оцем, захтевајући посебне поклоне и на послетку успевају да побегну и дођу до другог царства. Ипак, да би успеле да се удају за принца, јунакиње су најпре преобучене у мишју или медвеђу кожу и налазе се у позицији служавке. Оваква промена изгледа и статуса, поред улоге скривања од оца, има и својеврсну улогу у „проверама“ пред сам обред прелаза - свадбу.

\section{4. Зла свекрва}

Бајка из Вукове збирке Зла свекрва (AаTh 707) одликује се веома разгранатим наративним склопом у који су укључени мотиви рођења свадбе - порођаја - смрти главне јунакиње, а потом и судбине њене деце. ${ }^{30}$ Стога ова бајка представља редак пример у прегледаном корпусу јер уписује пун животни круг главне јунакиње. Као прогонитељ јавља се лик свекрве, која тек рођену јунакињину децу ставља у сандук ${ }^{31}$ и пушта низ реку, а на њихово место поставља троје мачади. Након претрпљеног понижења и болести, јунакиња умире. Ово је један од јединствених типова

29 Иако вероватно нема неко посебно симболичко значење, у извесном смислу могуће је наслутити да преображавање у овцу можда има обратни ритуални карактер у односу на овна, који је у свадбеним обредима „жртвени дар” (TROJANOVIĆ 2008: 75), али оваква тврдња би претила да пређе у „учитавање” садржаја.

30 У основи бајки овог приповедног круга јесте тип бајке о оклеветаној жени која рађа двоје или троје златне деце, а потом бива посрамљена и заточена или пак умире, те њена деца настављају као централни јунаци који ће такође бити прогоњени. Карактеристика овог типа бајки јесте и веома богат сижејно-мотивски склоп који се често грана у различитим правцима наративног тока, те у зависности од типа варијанте укључује чудесне метаморфозе, религиозне и хришћанске елементе или пак тип приповетке о девојци без руку.

31 У овом мотиву се крије извесна обредна симболика, јер како је већ речено, затварање у сандук често је део обреда иницијације. Деца су затворена у сандуку, а потом пристижу у друго царство где ће касније морати да прођу кроз провере и да реше задатке како би поново стекли свој статус у друштву и сами стигли до свадбе као крајњег циља. 
женских бајки, јер главна јунакиња пролази кроз све обреде прелаза, те обреде пријема, обреде прелазних стања и обреде одвајања. Најпре рођење (које се не описује), потом свадбу, трудноћу и порођај и напослетку смрт. Јунакиња умире и стога нема прилику да докаже своју невиност. У том погледу њена деца „постају медијатори и на себе преузимају улогу јунака, јер је први и прави јунак страдао пре него што је успео да се докаже" (ANTONIJEVIĆ 1991: 106).

\section{4. Потрага за изгубљеним мужем}

Круг бајки о потрази жене за изгубљеним мужем (AaTh 425) уједно припада и кругу бајки о мужу животињи (AaTh 425 C). Ове бајке су пандан много бројнијим мушким бајкама у којима је јунак у потрази за невестом. Такође, ове бајке на почетку подразумевају да је будући муж зачарана особа, тј. људско биће у зверском обличју (ANTONIJEVIĆ 1991: 115).

У прегледаном усменом корпусу бајке 3мија младожења $(\mathrm{V}, 9)^{32}$, Дете змија (Đ, 46) и Змија младожена (II) (M, 18) з3 представљају једноставније варијанте о зачараној особи и одликују се сажетијим наративним склопом, јер мотив потраге за мужем у овим бајкама изостаје.

Бајке Опет змија младожена (V, 10), Змија младожена (I) $(\mathrm{M}, 17)$ и њихова алтернативна варијанта Златокоси јунак у прасећој кожи (С̌ 1 , 41) развијају у потпуности мотив потраге јунакиње за изгубљеним мужем.

На почетку бајки (V, 10; M, 17) (AaTh 433 B, AaTh 425 C, AaTh 313 C) постоји мотив чудесног рођења, јер жена рађа змију. ${ }^{34}$ Након што змија изражава жељу за женидбом, те после обављеног свадбеног обреда, невеста/јунакиња крши забрану јер спаљује змијску кошуљу, те не пролази квалификујућу проверу „спремности да уђе у брак и и заволи необичног младожењу" (ANTONIJEVIĆ 1991: 136). Због тога је јунакиња осуђена на лутање и тражење супруга, по чему се ова бајка приближава наративној

32 У овој бајци уочава се „вид акције” који изостаје у другим варијантама где главну улогу преузима љуба: „Попут посвећених свештеница [...] жене знају како да од огња сачувају младића и поливају га водом. Тако се сједињују праелементи: ватра, вода и земља, јер је према етиолошким предањима и змија начињена од земље” (SAMARDŽIJA 2012: 19).

33 Ове варијанте представљају доста скраћене верзију, јер се завршавају смрћу змије младожење. У том погледу, мотив потраге потпуно изостаје.

34 Змија „спаја у себи мушку и женску, водену и ватрену симболику, негативно и позитивни начело. Својствена су јој апотропејска и штетна својства, она је отровна и лековита, нечисто створење, извор зла и истовремено снабдева човека чудесним способностима и има покровитељске функције” (SM 2001: 212). Њена хтонска природа „дефинише њену корелацију с подземним светом мртвих" (GURA 2005: 214). 
структури јуначке бајке у којој јунак одлази у потрагу и пролази кроз различите провере, те решава тешке задатке. Веома је интересантан мотив у којем јунакиња остаје трудна чак три године, тј. до оног тренутка док муж не пребаци руку преко ње. Ова фантастична и дуготрајна трудноћа указује на то да је јунакиња заправо у интервалу друштвене безвременcomu (LIČ 2002: 116), јер до порођаја не може доћи док не прође кроз све провере. У том погледу, у средишту ове бајке је својеврсни обред прелаза кроз који јунакиња мора да прође да би поново стекла супруга и родила дете. С тим у вези, фази маргиналности одговарала би јунакињина удаја за чудесног супруга. У фази сепарације јунакиња одлази да тражи мужа, те посећује Сунце и Месец, да би јој у потрази на крају помогао Ветар, откривши јој где се налази њен муж. Јунакињино лутање је симболичко, посматрано са космолошког аспекта, нарочито ако се у обзир узме фантастично трајање њене трудноће, јер све периодичне функције „везане су за велике космичке ритмове: женске периоде прате месечеве мене, трудноћа траје одређени број лунарних месеци; смењивање дана и ноћи, редослед месеци и повратак годишњих доба припадају истом систему" (LEVI-STROS 2008: 211). Фаза лиминалности обележена је јунакињиним одласком у онострани простор, тј. доњи свет, јер ветар зна где је њен муж зато што излази из земље, стога „нема сумње да је ветар управо тамо видео мужа наше јунакиње, што потврђује већ изнесени закључак да далеко царство у које он одлази и из кога је, у виду змије, и потекао јесте - свет мртвих" (ANTONIJEVIĆ 1991: 154). Удалеком ияарству јунакиња мора да прође последње провере и успе да замени лажну јунакињу. У фази агрегације јунакиња успева да поврати свој првобитни статус супруге, те и да роди сина.

\section{5. „На међи” мушке и женске бајке}

Бајка Отаи, и ғегове кћери (С̆, 48) (АаTh 514) представља јединствен пример у којем се женска бајка толико приближава обрасцу јуначке бајке, да готово преузима њену читаву структуру и сижејно мотивски склоп.

У средишту бајке је јунакиња која преобучена у мушко „одлази у свет". Преоблачење јој дозвољава да поседује коња ${ }^{35}$ и да пролази кроз све провере и решава задатке као и мушки јунак при освајању невесте. ${ }^{36}$

35 У претходно анализираним бајкама ниједна јунакиња није поседовала коња нити се коњ јављао у функцији помагача, јер је коњ јуначки атрибут.

36 Јунакиња ове бајке је „делија девојка, једина жена-младожења у датом корпусу народних бајки, јавља се као усамљен, али активан тип младожење. Почетни атрибути су му кућа, сабља, мушко одело, а стечени двор, крилати коњ, царева кћи као невеста. Жени се у медијалној позицији.” (MARKOVIĆ-ŠTRBAC 2004: 73). 
Упркос прерушавању, савладавање женидбених препрека показује се као немогуће, а потпуно освајање невесте оствариво је тек кад јунакиња прође кроз потпуну метаморфозу пола.

\section{6. У светлу обреда иницијације}

Посматрано са становишта обреда прелаза бајке Царева ћерка за Ђавола $(Ð, 28)$ и Оживела кралица $(Ð, 29)$ доносе веома јединствене мотиве када је посреди обред иницијације.

Бајка Царева ћерка за Ђавола је у односу на Оживелу краљииу ${ }^{37}$ доста богатија мотивима и одликује се сложенијим наративним склопом. У основи ове бајке је мотив јунакињиног лутања ноћу који је директно повезан са фигуром ђавола. Када јунакиња спозна да је ноћу одводи ђаво, умире и од оца тражи да јој испуни жељу: Татко, све је истина, ја умирем, али проклет да си ако ми не испуниш жељу, ако ме не сарании у ирквено двориште и ако ми свако вече не праћаш за вечеру по војника (Đ, 28). У том погледу, ова бајка се чини јединственом јер обухвата и смрт као обред прелаза, тј. девојчину сахрану: Цар се ражалости кад му ћерка умрла. Саранија га у ирквено двориште и ву праћаја вечеру по војника. (Đ, 28). Ипак, даље развијање мотива показује да није у питању права смрт, већ више она привремена и симболичка, каква се среће у обреду иницијације. Како девојка ноћу устаје из гроба, јасно је да није заправо мртва. У нашој традицији посмртно устајање из гроба директно је повезано са повампирењем. ${ }^{38}$ Ипак, да у овој бајци није реч о повампирењу указује део обреда иницијације у ком „кандидат може бити смештен у гроб ископан за њега" (РС 2004: 293) као и прелазни ритуал свадбе који следи. У том погледу, због веома блиске релације између смрти (гроба) и свадбе у овој бајци наслућује се и обрис посмртне свадбе ${ }^{39}$ као обичајно-обредног комплекса познатог нашој традицији.

У светлу обреда иницијације неизбежно је поменути и дотаћи се 37 Оживела кралица тематизује само последњу наративну секвенцу претходне бајке, тј. у њеној основи је само мотив сандука и свадбе.

38 „У својој митској пројекцији, покојник задржава основне лиминалне карактеристике неинтегрисаног појединца у ритуалном стању између овоземаљског и хтонског, покојниково повампирење је знак и упозорење недовршеном обредном процесу. Његов излазак из гроба значи преокретање овог процеса због немогућности интегрисања у други свет." (JOVANOVIĆ 2005: 154).

39 „У примитивним људским друштвима је правило да се сваки мушкарац ожени и да се свако женскиње уда чим им стигне време зато, и да момци и девојке, зрели за женидбу и удају, не треба да умру а да се не ожене, односно не удају." (ĐORĐEVIĆ 2002: 341).

„Према народном схватању, обавеза ступања у брак је егзистенцијални и социјални императив који се у случају смрти појединца испуњава фиктивно, ритуалом мртвачке свадбе." (JOVANOVIĆ 2005: 157) 
појединих мотива у бајкама Заклете жене (С̌, 55) и Дјевојка дала голубиици воде (С̌1, 83).

Бајка Заклете жене чини се јединственом у српском усменом корпусу по теми коју обрађује. Почетне наративне секвенце описују долазак седам солдата у једну кућу усред планине, у којој затичу златни сто и штап, а у којој живи седам змија, тј. седам заклетих жена. Овако представљена кућа одговара опису женске куће која опонаша мушке (PROP 2013: 148), а које представљају „институције својствене родовском уређењу” (PROP 2013: 134). У овакву кућу су иницијанти одлазили након завршетка чина иницијације, па је кућа служила као „уточиште за дошљаке - мушкарце" (PROP 2013: 137). Иако доста ређе појаве, женске куће преузимају на себе све карактеристике мушких кућа, па „као што девојка долази у мушку кућу, ти јунаци долазе у кућу насељену женама" (PROP 2013: 148).

Бајка Дјевојка дала голубици воде $(\check{C} 1,83)$ блиска је бајкама типа Плавобради, те је веома редак случај у прегледаном усменом корпусу. У овој бајци конституише се мотив забрањене собе у којој јунакиње затичу крв, а потом страдају. ${ }^{40}$ За Пропа је забрањена соба „генетски повезана са тајном одајом иницијацијских кућа, где се чувају светиње; она је тајна за неофита само током иницијације, после не. Ако уместо чудесног дара јунак види раскомадане лешеве, и то је повезано с иницијацијским искушавањима која укључују и сакаћења" (RADULOVIĆ 2009: 38).

\section{7. Обреди прелаза у књижевно-уметничком руху}

Обреди свакако у систему усмене традиције имају одређено значење и улогу. У том погледу, изучаваоци ритуалне школе с правом проналазе да је постављање тешких задатака повезано са обредима иницијациje, али при томе, како примећује Холбек, греше јер занемарују чињеницу да су тешки задаци и награде део бајке не само зато што припадају прошлости, већ су важни приповедачу и колективу у њиховом сопственом времену (HOLBEK 1987: 422).

Ипак, бајку као врсту народне књижевности треба посматрати најпре као књижевно-уметничку усмену творевину, а не као пуко спремиште традииије у које се просто транспонују архаични (магијски, обредни, митски, обичајни) слојеви.

Тако аспекти бајке који показују велику сличност са појединим 40 И она отвори врата. Кад она унутра, али то све сама крв, и юој испадне јабука из юедара што јој је био дао годподин кад је пошао од куће. Јабука се искрвави. Она је брже попане, стане је трти, али се не да; она је метне у недра, па изађе ван. Кад јој је господин дошао, иште јабуку, а кад види да је крвава рече јој: „Јесам ти рекао да ћеш умријети ако уђеш у девету комару, а ти ме нијеси хтјела послушати“. Узме је за руку, па је одведеде у девету комару, извади јој језик, па је објеси заю. (С̌1, 83). 
елемнтима обредног комплекса, стилизацијом народног казивача постају мотиви који су тек одраз традиције, а у бајци имају превасходно уметничку тенденцију, јер „док је обред затворена структура, чија је сврха јасна и неопходна друштву на одређеном развојном степену, бајка је тек занимљиво казивање, које је могуће варирати и продужавати новим епизодама" (SAMARDŽIJA 2011: 128).

Уношењем мотива у којима видимо сенке обреда прелаза постиже се, пре свега, својеврсна динамичност и напетост, нарочито у кругу приповедака о прогоњеној јунакињи.

\section{Цитирана литература}

ANTONIJEVIĆ 1991: Antonijević, Dragana. Značenje srpskih bajki. Beograd: SANU, 1991. [orig.] Антонијевић, Драгана. Значеюе српских бајки. Београд: CAHY, 1991.

ANTONIJEVIĆ 2013: Antonijević, Dragana. „Antropološko poimanje bajke kao optimističkog žanra”. Antropologija: Časopis centra za etnološka i antropološka istraživanja (CEAI) Filozofskog fakulteta Univerziteta u Beogradu Br. 13, sv. 1 (2013): 9-22.

AATH - AARNE, THOMPSON 1961: Aarne, Antti, Thompson, Stith. The types of the folktale: A classification and bibliography. Helsinki: Suomalainen tiedeakatemia, 1961.

BANDIĆ 1980: Bandić, Dušan. Tabu u tradicionalnoj kulturi Srba. Beograd: Beogradski izdavačko-grafički zavod, 1980.

BANDIĆ 2004: Bandić, Dušan. Narodna religija Srba u 100 pojmova. Beograd: Nolit, 2004. [orig.] Бандић, Душан. Народна религија Срба у 100 појмова. Београд: Нолит, 2004.

BETELHAJM 1979: Betelhajm, Bruno. Značenje bajki. prev. B. Vučićević. Beograd: Jugoslavija: Prosveta, 1979.

ČAJKANOVIĆ 2014: Čajkanović, Veselin. Iz srpske religije, mitologije, folklora: izabrane studije. Beograd: Evro-Giunti, 2014. [orig.] Чајкановић, Веселин. Из српске религије, митологије и фолклора: изабране студије. Београд: Evro-Giunti, 2014.

DANDES 2007: : Dundes, Alan. The meaning of folklore : the analytical essays of Alan Dundes, edited and introduced by Simon J.Bronner. Logan, Utah: Utah State University Press, 2007.

DETELIĆ 1992: Detelić, Mirjana. Mitski prostor i epika. Beograd: Srpska akademija nauka i umetnosti, 1992. [orig.] Детелић, Мирјана. Митски простор и епика. Београд: Српска академија наука и уметности, 1992.

DIMOSKI 2015: Dimoski, Sanja. Čudesno u nama : od bajke do psihoterapije. Beograd: Treći trg, 2015.

ĐORĐEVIĆ 2002: Đorđević, Tihomir. Životni krug: rođenje, svadba i smrt u verovanjima i običajima našeg naroda. Niš: Prosveta, 2002. [orig.] Ђорђевић, Тихомир. Животни круг: рођене, свадба и смрт у обичајима и 
верованима нашег народа. Ниш: Просвета, 2002.

ESTES 2017: Estes, Klarisa Pinkola. Žene koje trče s vukovima : mitovi i priče o arhetipu divlje žene. prev. M.Kostadinović. Podgorica: Nova knjiga, 2017.

FREJZER 1977: Frejzer, Džejms Džordž. Zlatna grana : proučavanje magije i religije. Knj. 1-2. prev. Ž. Simić. Beograd: Beogradski izdavačko-grafički zavod, 1977.

GREMAS 1987: Greimas, A.J. , Semántica estructural: investigación metodológica. Madrid: Gredos, 1987.

GURA 2005: Gura, Aleksandar. Simbolika životinja u slovenskoj narodnoj tradiciji. prev. Lj. Joksimović. Beograd: Brimo, 2005.[orig.] Гура, Александар. Симболика животиюа у словенској народној традицији. прев. Љ.Јоксимовић. Београд: Бримо, 2005.

HENDERSON 2017: Henderson, Džozef. „Drevni mitovi i savremeni čovek”. Čovek $i$ njegovi simboli. prev. E. Vasiljević. Podgorica: Nova knjiga, 2017.

HOLBEK 1987: Holbek, Bengt. Interpretation of fairy tales. Danish Folklore in a European Perspective. Helsinki: Suomalainen tiedeakatemia, 1987.

JOVANOVIĆ 2005: Jovanović, Bojan. Magija srpskih obreda u životnom ciklusu pojedinca. Beograd: Narodna knjiga, 2005. [orig.] Јовановић, Бојан. Магија српских обреда у животном ииклусу појединца. Београд: Народна књига, 2005.

LATKOVIĆ 1987: Latković, Vido. Narodna književnost 1. Beograd: Naučna knjiga, 1987. [orig.] Латковић, Видо. Народна книжевност 1. Београд: Научна књига, 1987.

LEVI-STROS 2008: Levi-Stros, Klod. Mitologike. 3, Poreklo ponašanja za trpezom. Prev. S. Stojanović. Novi Sad: Kiša, 2008.

LIČ 2002: Lič, Edmund. Kultura i komunikacija : logika povezivanja simbola : uvod u primenu strukturalističke analize u socijalnoj antropologiji. prev. B. Hlebec. Beograd: Biblioteka XX vek, 2002.

MARKOVIĆ-ŠTRBAC 2004: Marković-Štrbac, Svetlana. Motiv ženidbe u srpskoj narodnoj bajci. Beograd: Čigoja štampa, 2004.[orig.] Марковић-Штрбац, Светлана. Мотив женидбе у српској народној бајци. Београд: Чигоја штампа, 2004.

MELETINSKI 1983: Meletinski, Jeleazar. Poetika mita. prev. J. Janićijević. Beograd: Nolit, 1983.

POPOVIĆ 1905: Popović, Pavle. Pripovetka o devojci bez ruku: studija iz srpske i jugoslovenske književnosti. Beograd: Srpska kraljevska akademija, 1905. [orig.] Поповић, Павле. Приповетка о девојии без руку: студија из српске и југословенске кюижевности. Београд: Српска краљевска академија, 1905.

PROP 2012: Prop, Vladimir. Morfologija bajke. prev. P. Vujičić. Beograd: Čigoja štampa, 2012.

PROP 2013: Prop, Vladimir. Istorijski koreni čarobne bajke. prev. M. Kosanović. Beograd: Izdavačka knjižarnica Zorana Stojanovića, 2013. [orig.] Проп, Владимир. Историјски корени чаробне бајке. прев. М. Косановић. Београд: Издавачка књижарница Зорана Стојановића, 2013. 
RADENKOVIĆ 1996: Radenković, Ljubinko. Simbolika sveta u narodnoj magiji Južnih Slovena. Niš: Prosveta, 1996. [orig.] Раденковић, Љубинко. Симболика света у народној магији Јужних Словена. Ниш: Просвета, 1996.

RADULOVIĆ 2009: Radulović, Nemanja. Slika sveta u srpskim narodnim bajkama. Beograd: Institut za književnost i umetnost, 2009. [orig.] Радуловић, Немања. Слика света у српским народним бајкама. Београд: Институт за књижевност и уметност, 2009.

RS 2004: Gerbran, Alen. Ševalije, Žan. Rečnik simbola : mitovi, snovi, običaji, postupci, oblici, likovi, boje, brojevi. prev. P. Sekeruš i dr. Novi Sad: Stylos, 2004.

SAMARDŽIJA 2011: Samardžija, Snežana. Oblici usmene proze. Beograd: Službeni glasnik, 2011. [orig.] Самарџија, Снежана. Облици усмене прозе. Београд: Службени гласник, 2011.

SAMARDŽIJA 2012: Samardžija, Snežana. ,,Ko se krije ispod zmijskog svlaka? Metamorfoze u žanrovskom sistemu”. Guje i jakrepi: književnost, kultura. Ur. Mirjana Detelić i Lidija Delić. Beograd: Balkanološki institut SANU, 2012. str. 13-41. [orig.] Самарџија, Снежана. „Ко се крије испод змијског свлака? Метаморфозе у жанровском систему" Гује и јакрепи: књижевност, култура. ур. Мирјана Детелић и Лидија Делић. Београд: Балканолошки институт САНУ, стр. 13-41.

SM 2001: Slovenska mitologija: enciklopedijski rečnik, red. S. Tolstoj, Lj. Radenković. Beograd: Zepter book world, 2001.[orig.] Словенска митологија: енциклопедијски речник. ред. С. Толстој, Љ. Раденковић. Београд: Zepter book world, 2001.

TROJANOVIĆ 2008: Trojanović, Sima. Glavni srpski žrtveni običaji. Beograd: Službeni glasnik, 2008. [orig.] Тројановић, Сима. Главни српски жртвени обичаји. Београд: Службени гласник, 2008.

VAN GENEP 2005: Van Genep, Arnold. Obredi prelaza: sistematsko izučavanje rituala. prev. J. Loma. Beograd: Srpska književna zadruga, 2005. [orig.] Ван Генеп, Арнолд. Обреди прелаза: систематско изучаваюе ритуала, прев. Ј. Лома. Београд: Српска књижевна задруга, 2005.

\section{Извори}

B - BOVAN 1980: Bovan, Vladimir. Narodna književnost Srba na Kosovu 5. Narodne pripovetke I. Priština: Jedinstvo, 1980. [orig.] Бован, Владимир. Народна књижевност Срба на Косову 5. Народне приповетке I. Приштина: Јединство, 1980.

Č - ČAJKANOVIĆ 1999: Čajkanović, Veselin. Srpske narodne pripovetke. Beograd: Gutenbergova galaksija, 1999. [orig.] Чајкановић, Веселин. Српске народне приповетке. Београд: Гутенбергова Галаксија, 1999.

Č 1 - ČAJKANOVIĆ 2001: Čajkanović, Veselin. Čudotvorni prsten. prir. Nenad Ljubinković. Niš: Prosveta, 2011. Srpske narodne pripovetke, 1929. [orig.] Чајкановић, Веселин. Чудотворни прстен, прир. Ненад Љубинковић. Ниш: Просвета, 2001. Српске народне приповетке, 1929.

Đ - ĐORĐEVIĆ 1988: Đorđević, Dragutin. Srpske narodne pripovetke i predanja iz 
leskovačke oblasti. prir. Nada Milošević-Đorđević. Beograd: Srpska akademija nauka i umetnosti, 1988. [orig.] Ђорђевић, Драгутин. Српске народне приповетке и предаға из лесковачке области. прир. Нада МилошевићЂорђевић. Београд: Српска академија наука и уметности, 1988.

M - MARKOVIĆ 2004: Marković, Snežana. Pripovetke i predanja iz Levča: novi zapisi. Beograd: Čigoja štampa, 2004. [orig.] Марковић, Снежана. Приповетке u предана из Левча: нови записи. Београд: Чигоја штампа, 2004.

V - KARADŽIĆ STEFANOVIĆ 1975: Karadžić Stefanović, Vuk. Srpske narodne pripovijetke. Beograd: Nolit, 1975. Вес̌, 1853. [orig.] Караџић, Стефановић, Вук. Српске народне приповјетке. Београд: Нолит, 1975. Беч, 1853.

Z - ZLATKOVIĆ 2005: Zlatković, Dragoljub. Pripovedanja iz pirotskog kraja. Pirot: Pi-Press, 2005. [orig.] Златковић, Драгољуб. Приповедағь из пиротског краја. Пирот: Pi-Press, 2005.

Aleksandra Z. Miljanović

\section{THE RITES OF PASSAGE IN SERBIAN FEMININE FAIRY TALES}

The paper is giving the analysis of the rites of passage in the Serbian feminine fairy tales, where the rites of passage are mostly identified in the motives of initiation, pregnancy, and wedding. The majority of the paper is devoted to the female initiation, which implies certain topics, motives, and spaces. In its roots, female initiation is associated with the locale of the house (Cinderella). Freely fusing with other types of fairy tales, even with fading of the mere rites in the tradition, the heroine would gradually leave the house (fairy tales about the stepmother and the stepdaughter), so that she could eventually, like the heroes, "go into the world" (fairy tales about search for the lost husband).

Keywords: feminine fairy tale, rites of passage, initiation, Cinderella, fairy tales about the persecuted heroine, fairy tales about the stepmother and the stepdaughter, fairy tales about search for the lost husband 